\title{
ANALISIS PROKSIMAT DAN KEKUATAN GEL AGAR - AGAR DARI RUMPUT LAUT KERING PADA BEBERAPA PASAR TRADISIONAL
}

\author{
Nia Yuliani*, Noviana Maulinda dan RTM Sutamihardja \\ FMIPA Universitas Nusa Bangsa \\ Jl. K. H. Sholeh Iskandar, Cimanggu, Tanah Sareal-Bogor 16166 \\ *e-mail : niayuliani88@yahoo.co.id
}

\author{
ABSTRACT \\ Proximate and Gel Strenght Analysis of Agar from \\ Dry Seaweed in some Traditional Markets
}

\begin{abstract}
Seaweeds are good material in processing to intermedite and finish product like agar - agars in Indonesia still in a semi-modern and traditional methods. This led Indonesia still make import the agar gelatin from other countries. The purpose of the study was to increas use the dried seaweed in traditional markets for the products of gelatin and to provide the nutrition information, like water content, ash content, crude fat, protein, carbohydrates, crude fiber, the levels of sulfate and gel strength of processed gelatin from dry seaweed. Dried seaweed used in this study, obtained from a traditional market in Bogor, Bekasi and Jakarta. Proximate result and the gel strength from extracted agar powder samples would compared with commercial flour agar. Research results obtained extracted agar - agar powder samples had lower chemical content and gel strength than the commercial agar, but it still could be used as food, although in very small amounts.
\end{abstract}

Keywords : dry seaweeds, proximate analysis, gel strength, agar-agar

\begin{abstract}
ABSTRAK
Pengolahan rumput laut menjadi bahan olahan seperti agar - agar di Indonesia masih secara tradisional dan semi modern. Hal ini menyebabkan Indonesia masih mengimpor agar - agar dari negara lain. Manfaat dan tujuan penelitian ini adalah memanfaatkan rumput laut kering yang banyak terdapat di pasar - pasar tradisional menjadi produk agar - agar dan memberikan informasi kandungan nutrisi yang berupa air, abu, lemak kasar, protein, karbohidrat, serat kasar, kadar sulfat serta kekuatan gel dari agar -agar hasil olahan rumput laut kering. Rumput laut kering yang digunakan pada penelitian ini, diperoleh dari pasar tradisional di Bogor, Bekasi dan Jakarta. Hasil proksimat dan kekutan gel dari sampel tepung agar - agar hasil ekstrak kemudian dibandingkan dengan tepung agar - agar komersial berdasarkan hasil penelitian diperoleh sampel tepung agar - agar hasil ekstraksi dengan kandungan kimia dan kekuatan gel yang lebih rendah dari agar - agar komersial, tetapi masih dapat dimanfaatkan sebagai bahan pangan walaupun dalam jumlah yang sedikit.
\end{abstract}

Kata kunci : rumput laut kering, analisis proksimat, kekuatan gel, agar - agar

\section{PENDAHULUAN}

Rumput laut tergolong tumbuhan tingkat rendah, umumnya tumbuh melekat pada substrat tertentu, tidak mempunyai akar, batang maupun daun sejati. Rumput laut tumbuh di alam dengan melekat pada karang, lumpur, pasir, batu dan benda keras lainnya. Rumput laut dapat pula melekat pada tumbuhan lain secara epifitik. Pertumbuhan dan penyebaran rumput laut sangat tergantung dari faktor faktor oseanografi serta jenis substrat dasarnya (Anggadiredja et. al., 2006).
Jenis rumput laut komersial yang sudah dikembangkan di Indonesia yaitu Eucheuma sp., Hypnea sp., Gracilaria sp., Gelidium sp., dan Sargassum sp. (Anggadiredja et. al., 2006).

Luasnya perairan laut Indonesia serta keragaman jenis rumput laut merupakan cerminan dari potensi rumput laut Indonesia. Berdasarkan 782 jenis rumput laut yang ada di perairan Indonesia, hanya 18 jenis dari 5 genus (marga) yang telah diperdagangkan. Kelima genus (marga) tersebut hanya 
genus - genus Eucheuma dan Gracilaria yang sudah dibudidayakan (Anggadiredja et.all, 2006).

Rumput laut di Indonesia baru sebagian kecil dilakukan pengolahan menjadi produk olahan seperti agar - agar . Rumput laut tersebut sebagian besar diekspor dalam bentuk rumput laut kering. Rumput laut hasil pemetikan dari alam dibersihkan dari kotoran - kotoran yang menempel seperti pasir, karang, garam dan kotoran lainnya. Setelah bersih dicuci dengan air tawar sampai berwarna putih, kemudian dikeringkan. Pencucian dan pengeringan dilakukan beberapa kali sampai diperoleh rumput laut kering yang bersih dan putih barulah dkemas dan diekspor (Istini, et.al, 1986).

Pengolahan rumput laut menjadi agar - agar di dalam negeri masih pada tahap semi tradisional, yaitu dalam bentuk lembaran, batangan, maupun tepung. Produksi agar - agar di Indonesia hanya untuk memenuhi kebutuhan dalam negeri yaitu digunakan sebagai bahan makanan. Perusahaan agar - agar di Indonesia sebagian besar hanya melakukan pengepakan saja. Indonesia sampai saat ini masih mengimpor agar - agar kualitas baik dari negara lain (Istini, et.al, 1986).

Guna meningkatkan produksi dan kualitas agar - agar di Indonesia maka rumput laut kering yang banyak dijual di pasar-pasar tradisional perlu dilakukan pengolahan menjadi agar - agar serta menganalisis kandungan nutrisi secara kimia dan kekuatan gelnya. Oleh sebab itu dilakukan penelitian ini, dengan tujuan untuk memberikan informasi kepada masyarakat umum tentang kandungan nutrisi agar - agar yang baik pada suatu bahan pangan yang sesuai dengan Standar Nasional Indonesia (SNI).

Dewasa ini penggunaan agar agar semakin berkembang selain digunakan sebagai makanan, digunakan juga dalam bidang bioteknologi dan bahan baku industri, seperti tekstil, kosmetik, farmasi, kertas, fotografi, dan cat. Fungsi utama agar - agar adalah sebagai pemantap (stabilizer), pembuat emulsi (emulsifier), bahan pengental (thickening), bahan pengisi (icing) dan bahan pembuat gel (gelling agent).

Agar atau sering juga disebut agar-agar merupakan salah satu produk olahan yang berasal dari rumput laut jenis Gracilaria sp. dan Gelidium sp. dengan cara ekstraksi. Pengolahan agar - agar di dalam negeri masih pada tahap semi tradisional, yaitu dalam bentuk lembaran, batangan, maupun tepung. Agar - agar merupakan polisakarida yang terdiri dari dua fraksi yaitu agarosa dan agaropektin. Agarosa merupakan komponen yang netral atau tidak bermuatan, sedangkan agaropektin adalah komponen yang bermuatan (Rachmad \& Abdullah, 2002). Perbandingan kedua komponen tersebut tergantung pada jenis rumput laut penghasil agar yang digunakan (umumnya kandungan agarosa sekitar 55 - 56\%) (Rasyid, 2004a).

Agar - agar memiliki sifat seperti gelatin, larut dalam air panas. Pada suhu $35-39{ }^{\circ} \mathrm{C}$ berbentuk padatan dan mencair pada suhu $85-95{ }^{\circ} \mathrm{C}$ serta memiliki kemampuan membentuk gel. Pengolahan rumput laut menjadi agar - agar dilakukan dengan cara ekstraksi. Ekstraksi dapat dilakukan dalam suasana asam, basa dan netral tergantung jenis rumput laut yang digunakan (Champan \& Champan, 1980).

\section{METODE PENELITIAN}

\section{Bahan}

Bahan - bahan yang digunakan adalah rumput laut kering yang sudah dibersihkan, $\mathrm{NaOH}, \mathrm{CaO}, \mathrm{HCl}, \mathrm{K}_{2} \mathrm{SO}_{4}$, $\mathrm{NaCl}$, Polietilen Glikol (PEG) 6000, asam borat, indikator campuran (brom cresolgreen : metil merah), akuades, larutan Luff, Petroleum Eter, Natrium Bikromat, $\mathrm{KCl}$, Na-tiosulfat, $\mathrm{KIO}_{3}, \mathrm{KI}$, $\mathrm{H}_{2} \mathrm{SO}_{4}, \mathrm{H}_{2} \mathrm{O}_{2}, \mathrm{BaCl}_{2}$, larutan pati dan Selenium.

\section{Peralatan}

Alat - alat yang digunakan adalah neraca analitik, labu Kjeldahl, kertas whatman saring, oven, tanur, water bath, Texture Analyzer, sentrifuse, batang 
pengaduk, gelas piala, lemari es, filter 150 mesh, cawan porselen, spatula, esikator, soxhlet, stirrer, erlenmeyer, buret, batu didih, kertas lakmus, pipet tetes, pipet volumetrik, piper mohr, gelas ukur, pendingin tegak, labu ukur, hot plate, labu penyari dan cetakan agar - agar.

\section{Prosedur Kerja}

Rumput laut kering yang telah bersih sebanyak $100 \mathrm{~g}$, dipotong kasar direndam dan dicuci dengan menggunakan air bersih. Rumput laut kemudian dipucatkan dengan larutan $\mathrm{CaO} 1 \%$ selama 1 jam. Rumput laut lalu dicuci kembali hingga $\mathrm{pH}$ netral dan dilanjutkan dengan tahapan praperlakuan alkali. Pada praperlakuan alkali, rumput laut dimasukkan ke dalam $\mathrm{NaOH}$ 6\% dengan perbandingan $1: 10$. Selama praperlakuan alkali rumput laut dipanaskan pada suhu $60^{\circ} \mathrm{C}$ selama $1 \mathrm{jam}$. Proses praperlakuan alkali selesai, rumput laut dicuci kembali dengan air hingga $\mathrm{pH}$ netral. Rumput laut kemudian diekstraksi dengan air, dengan perbandingan 1 : 20 dan dipanaskan pada suhu $85^{\circ} \mathrm{C}$ selama 2 jam.

Rumput laut yang telah diekstraksi lalu disaring dengan menggunakan saringan berukuran 150 mesh. Filtrat hasil penyaringan ditambahkan PEG 6000 sebanyak 20\% (b/v) dan $\mathrm{NaCl}$ sebanyak $1 \%$ (b/v) dan dipanaskan kembali selama 30 menit. Setelah proses pemanasan selesai filtrat disaring kembali. Filtrat dimasukkan ke dalam pan-pan pencetak dan didiamkan selama 24 jam pada suhu kamar, kemudian dikeringkan pada suhu $50-55^{\circ} \mathrm{C}$. Setelah kering lalu di grinder sehingga menjadi tepung (Darmawan, et.al, 2006).

\section{Penentuan Kadar Air}

Sampel sebanyak $2 \mathrm{~g}$ dimasukkan ke dalam cawan yang telah bebas lemak lalu ditimbang dan dicatat, kemudian cawan berisi sampel dimasukkan ke dalam oven pada suhu $105{ }^{\circ} \mathrm{C}$ selama 4 jam. Cawan kemudian ditimbang.

\section{Penentuan Kadar Abu}

Sampel sebanyak $2 \mathrm{~g}$ dimasukkan ke dalam cawan dan dimasukkan ke dalam tanur dengan suhu $600{ }^{\circ} \mathrm{C}$, selama 5 jam. Cawan kemudian ditimbang dan dicatat.

\section{Penentuan Kadar Lemak Kasar}

Sampel sebanyak $2 \mathrm{~g}$ dimasukkan dalam selongsong. Selongsong yang berisi sampel dimasukkan ke dalam labu penyari (alat soxhlet) dan diberi pelarut Petroleum Eter sebanyak $150 \mathrm{~mL}$, lalu diekstraksi. Ekstraksi dilakukan selama 4 jam. Labu penyari lalu dikeringkan dalam oven pada $105{ }^{\circ} \mathrm{C}$ selama $1 \mathrm{jam}$. Kemudian ditimbang dan dicatat.

\section{Penentuan Kadar Protein}

Sampel ditimbang dengan teliti sebanyak 0,1 gram, dimasukkan ke dalam labu Kjeldahl, ditambahkan 0,65 gram campuran Selenium dan 2,5 mL $\mathrm{H}_{2} \mathrm{SO}_{4}$ pekat. Larutan diencerkan dengan menambahkan akuades sebanyak $10 \mathrm{~mL}$. Larutan dipindahkan ke dalam alat destilasi dan dibilas dua atau tiga kali dengan $3 \mathrm{~mL}$ akuades. Larutan di

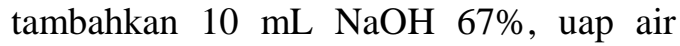
dialirkan melewati alat destilasi dan destilat ditampung ke dalam erlenmeyer yang berisi $10 \mathrm{~mL}$ asam borat dan 2-3 tetes indikator BCG/MM (1:1), waktu destilasi ditentukan selama 5 menit (stopwatch). Erlenmeyer yang berisi sulingan dititar dengan $\mathrm{H}_{2} \mathrm{SO}_{4} 0,01 \mathrm{~N}$, kemudian dicatat sebagai volume contoh.

\section{Penentuan Kadar Karbohidrat}

Sampel sebanyak $1 \mathrm{~g}$ dimasukkan dalam erlenmeyer dan ditambahkan 100 $\mathrm{mL} \mathrm{HCl} 3 \%$. Larutan dihidrolisis selama 2,5 jam dengan cara dipasangkan pada pendingin tegak. Larutan kemudian didinginkan dan dinetralkan dengan $25 \mathrm{~mL}$ $\mathrm{NaOH} 4 \mathrm{~N}$. Larutan lalu dimasukkan ke dalam labu takar $250 \mathrm{~mL}$ dan ditepatkan dengan akuades sampai tanda tera. Larutan disaring dengan kertas saring dan ditampung dalam gelas piala. Larutan 
sebanyak $10 \mathrm{~mL}$ dipipet dan dimasukkan dalam erlenmeyer $250 \mathrm{~mL}$ kemudian ditambahkan $25 \mathrm{~mL}$ larutan luff dan beberapa batu didih lalu dididihkan selama 10 menit di bawah pendingin tegak.

Larutan lalu ditambahkan $20 \mathrm{~mL}$ KI $20 \%$ dan $25 \mathrm{~mL} \mathrm{H}_{2} \mathrm{SO}_{4} 25 \%$. Larutan kemudian dititrasi dengan Na-tiosulfat 0,1 $\mathrm{N}$ (yang telah distandardisasi). Titrasi dihentikan bila larutan berubah menjadi warna kuning gading. Larutan kemudian ditambahkan indikator pati hingga larutan berwarna biru dan titrasi dilanjutkan hingga larutan berwarna putih susu.

\section{Penentuan Kadar Serat kasar}

Sampel sebanyak $1 \mathrm{~g}$ didestruksi dalam $50 \mathrm{~mL} \mathrm{H}_{2} \mathrm{SO}_{4} 0,3 \mathrm{~N}$ selama 30 menit. Setelah itu ditambahkan $25 \mathrm{~mL}$ $\mathrm{NaOH} \quad 1,5 \quad \mathrm{~N}$, kemudian dididihkan kembali selama 30 menit. Filtrat disaring melalui kertas saring Whatman 42 yang telah dikeringkan dalam oven pada suhu 105-110 ${ }^{\circ} \mathrm{C}$, selama 1 jam. Hasil saringan dicuci dengan $50 \mathrm{~mL}$ akuades panas, 50 $\mathrm{mL}_{2} \mathrm{SO}_{4} 0,3 \mathrm{~N}, 50 \mathrm{~mL}$ akuades panas dan $50 \mathrm{~mL}$ aseton. Kertas saring dan isinya dimasukkan ke dalam cawan porselin yang telah dikeringkan dalam oven pada suhu $105-110{ }^{\circ} \mathrm{C}$ selama 1 jam. Cawan berisi sampel kemudian diabukan dalam tanur pada suhu $600{ }^{\circ} \mathrm{C}$ selama 1 jam. Cawan lalu didinginkan dalam eksikator, ditimbang dan dicatat.

\section{Pengukuran Kadar Sulfat}

Sampel agar - agar sebanyak $1 \mathrm{~g}$ dimasukkan dalam erlenmeyer dan ditambahkan $50 \quad \mathrm{~mL} \quad \mathrm{HCl} \quad 0,2 \quad \mathrm{~N}$. Erlenmeyer berisi sampel dipasang pada penangas tegak dan dipanaskan sampai mendidih, kemudian direfluks selama 1 jam. Larutan ditambahkan dengan $25 \mathrm{~mL}$ $\mathrm{H}_{2} \mathrm{O}_{2} \quad 10 \%$ dan refluks dilanjutkan kembali selama 5 jam. Larutan kemudian dipindahkan ke gelas piala $600 \mathrm{~mL}$, dipanaskan sampai mendidih selama 2 jam sambil diaduk, lalu ditambahkan $10 \mathrm{~mL}$ $\mathrm{BaCl}_{2} 10 \%$, setetes demi setetes. Endapan yang terbentuk kemudian disaring menggunkan kertas Whatman 1, lalu dicuci dengan akuades mendidih sampai bebas klorida. Kertas saring dikeringkan dalam oven kemudian diabukan pada suhu 800 ${ }^{\circ} \mathrm{C}$ dalam tanur sampai didapatkan abu yang berwarna putih. Abu yang diperoleh didinginkan dalam eksikator dan ditimbang.

\section{Pengukuran Kekuatan Gel ( Gel Strength)}

Sampel sebanyak 0,90 gram ditambahkan 0.18 g KCl., ditambahkan 80 $\mathrm{mL}$ akuades dalam gelas piala, lalu dipanaskan sampai $80{ }^{\circ} \mathrm{C}$ sambil terus diaduk. Larutan panas kemudian dituangkan ke dalam cawan untuk dipadatkan dan disimpan pada suhu $20{ }^{\circ} \mathrm{C}$ selama 1 jam. Kekuatan gel diukur menggunakan Stevens LRFA Texture Analyzer.

\section{HASIL DAN PEMBAHASAN}

\section{Kadar Air}

Kadar air merupakan karakteristik yang sangat berpengaruh terhadap bahan makanan, terutama terhadap penampakan, tekstur, dan citarasa makanan. Kadar air yang tinggi mengakibatkan bakteri, kapang dan khamir mudah tumbuh, sehingga akan terjadi perubahan pada bahan pangan (Winarno, 1991). Kadar air merupakan salah satu alasan dalam pengolahan bahan makanan dan sangat mempengaruhi mutu bahan pangan. Air sering dikurangi dengan cara penguapan, pengentalan dan pengeringan. Kadar air yang tinggi pada bahan makanan akan memudahkan terjadinya perubahan kimia dan biokimia, serta pertumbuhan mikroorganisme selama masa penyimpanan (Hall, 1970).

Kadar air yang disyaratkan oleh SII untuk rumput laut kering berkisar antara $15-32 \%$ (Soegiarto \& Sulistyo, 1985), sedangkan kadar air maksimal yang disyaratkan oleh SNI untuk agar - agar berkisar antara 15-24\% (Angka \& Suhartono, 2000). Menurut Subaryono, et.al, (2003) kadar air agar - agar adalah kurang dari $14 \%$. Kadar air pada rumput laut akan berpengaruh terhadap rendemen 
agar - agar yang dihasilkan. Nilai rataan kadar air pada sampel rumput laut kering dan tepung agar - agar hasil ekstrak Bekasi, Jakarta dan Bogor, dapat dilihat pada Gambar 6.

Gambar 6 menunjukkan bahwa kadar air rataan pada sampel rumput laut kering Bekasi, Jakarta dan Bogor berturutturut adalah sebesar $14,03 \% ; 20,76 \%$; dan $23,16 \%$. Kadar air tersebut sesuai dengan yang disyarat SII untuk dilakukan pengolahan menjadi agar-agar yaitu 15$32 \%$. Sedangkan kadar air pada sampel tepung agar - agar hasil ekstraksi rumput laut kering tersebut berturut - turut sebesar $1,27 \% ; 3,05 \%$ dan $1,13 \%$. Hasil ini sesuai dengan syarat yang dikutip menurut Subaryono, et.al, (2003) bahwa kadar air agar - agar yaitu kurang dari $14 \%$. Bila dibandingkan dengan tepung agar - agar komersil yaitu $15,08 \%$, tepung agar - agar hasil ekstrak lebih kecil, hal ini dapat disebabkan oleh proses pengeringan, jenis dan sumber rumput laut kering yang digunakan. Berdasarkan hasil penelitian menunjukkan adanya penurunan kadar air setelah dilakukan ekstraksi, sedangkan kadar air sampel tepung agar - agar hasil ekstraksi relatif sama. Hal ini karena proses pengurangan jumlah air dan pengeringan terhadap agar yang dihasilkan untuk semua perlakuan adalah sama yaitu proses pengeringan dengan menggunakan oven pada suhu $50-55^{\circ} \mathrm{C}$ selama 24 jam.

\section{Kadar Abu}

Abu merupakan unsur mineral zat anorganik yang tidak mudah menguap dan merupakan sisa yang tertinggal setelah contoh dibakar dan dipijarkan sampai bebas karbon dan air. Kadar abu yang terkandung pada suatu produk menunjukkan tingkat kemurnian produk tersebut. Tingkat kemurnian sangat dipengaruhi oleh komposisi dan kandungan mineralnya (Darmawan, et.al, 2006).
Menurut Fitri (1992), kadar abu dari agar - agar sangat menentukan proses lanjutan pemisahan agarosa dengan agaropektin. Kadar abu pada rumput laut kering 1972 dalam Fitri 1992), sedangkan kadar abu yang disyaratkan oleh SNI untuk agar - agar adalah kurang dari 4\% (Angka $\&$ Suhartono, 2000). Nilai rataan kadar abu pada sampel rumput laut kering dan tepung agar - agar hasil ekstrak Bekasi, Jakarta, dan Bogor dapat dilihat pada Gambar 7.

Gambar 7 menunjukkan nilai rataan kadar abu masing-masing sampel rumput laut kering Bekasi, Jakarta, dan Bogor berturut - turut adalah 1,34\%; 1,63\%; dan 1,09\%. Sedangkan kadar abu pada sampel tepung agar - agar hasil ekstrak berturut-turut adalah $0,29 \% ; 0,55 \%$ dan $0,38 \%$. Berdasarkan data penelitian yang diperoleh, sampel rumput laut kering dan sampel tepung agar - agar hasil ekstrak memenuhi syarat standar FAO dan SNI yaitu kurang dari $4 \%$.

Berdasarkan data yang diperoleh bahwa kadar abu pada sampel rumput laut kering lebih besar dibandingkan kadar abu pada sampel tepung agar - agar setelah diekstrak, hal ini diduga karena kandungan mineral rumput laut yang tinggi dan masih adanya sisa-sisa karang atau pasir yang masih terbawa. Pembersihan dan pencucian saat proses pengolahan rumput laut kering menjadi tepung agar - agar menyebabkan pasir, karang, dan bendabenda asing lainnya yang masih menempel terbuang, sehingga kadar abu pada sampel tepung agar - agar menurun.

Kadar abu sampel tepung agar agar hasil ekstrak bila dibandingkan dengan sampel komersil yaitu sebesar $0,16 \%$, memiliki kadar abu yang lebih besar. Hal ini dapat disebabkan oleh bahan anorganik yang terdapat dalam agar - agar, juga merupakan sisa - sisa garam yang berasal dari bahan baku rumput laut kering serta sisa - sisa penambahan $\mathrm{NaCl}$ pada saat dilakukan ekstraksi. 


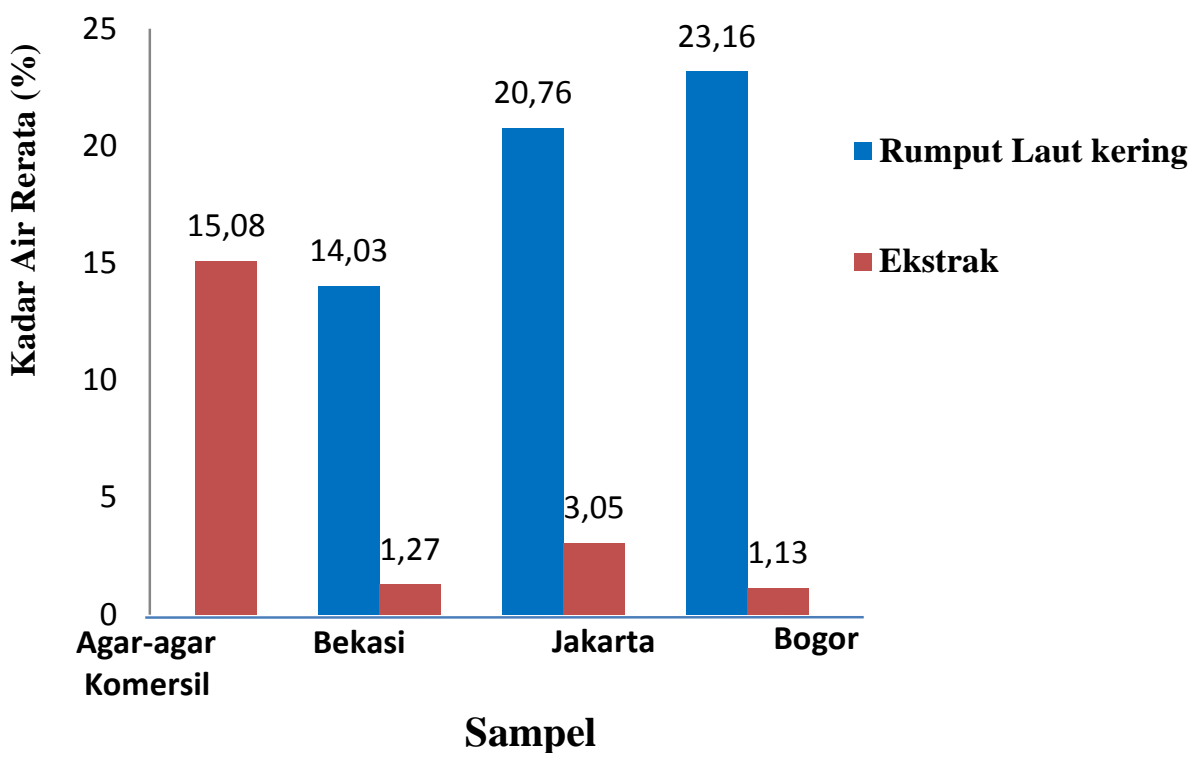

Gambar 6. Kadar Air Rerata pada Rumput Laut Kering dan Hasil Ekstraknya

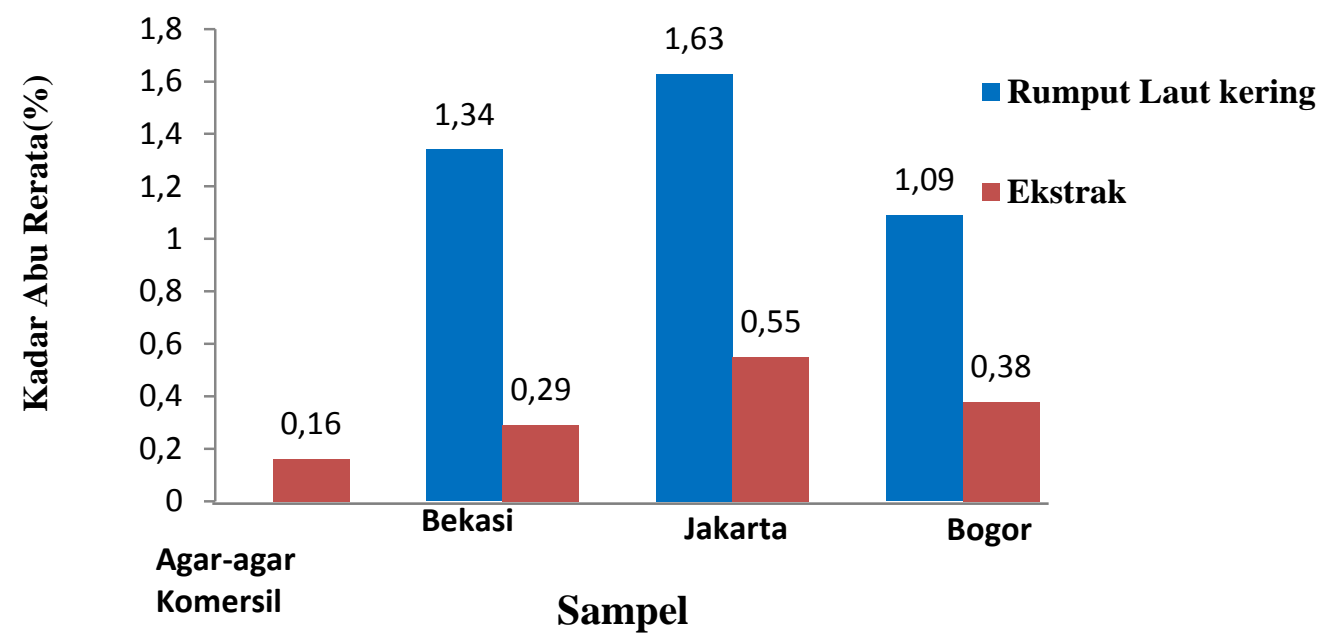

Gambar 7. Kadar Abu Rerata pada Rumput Laut Kering dan Hasil Ekstraknya

\section{Kadar Lemak Kasar}

Lemak dan minyak merupakan unsur yang sangat penting untuk menjaga kesehatan tubuh manusia. Komponen lemak dalam agar - agar terdapat dalam jumlah yang kecil dan merupakan pelengkap pada agar - agar. Kadar lemak yang disyaratkan FAO (1972) untuk rumput laut kering sebesar kurang dari 1,2\% (Fitri, 1992), sedangkan kadar lemak untuk agar - agar sebesar 0,1\% (Susanto, et.al, 1978). Nilai rataan kadar lemak kasar pada rumput laut kering dan produk tepung agar - agar hasil ekstrak Bekasi, Jakarta, dan Bogor dapat dilihat pada Gambar 8. 
Gambar 8 menunjukkan nilai rataan kadar lemak kasar pada masing masing sampel rumput laut kering Bekasi, Jakarta, dan Bogor berturut - turut adalah sebesar $0,36 \% ; \quad 0,92 \%$ dan $0,34 \%$. Sedangkan nilai rataan kadar lemak kasar pada sampel tepung agar - agar hasil ekstraksi berturut - turut adalah $0,11 \%$; $0,16 \%$; dan $0,32 \%$. Kadar lemak kasar sampel tepung agar - agar hasil ekstrak bila dibandingkan dengan sampel tepung agar - agar komersil yaitu sebesar $0,16 \%$, menunjukkan hasil yang tidak jauh berbeda. Setelah mengalami proses ekstraksi dengan perlakuan yang sama, ketiga sampel tersebut menunjukkan kadar lemak kasar yang tidak jauh berbeda.

Berdasarkan data yang didapatkan, diketahui bahwa kadar lemak kasar pada sampel tepung agar - agar hasil ekstrak lebih kecil bila dibandingkan dengan sampel rumput laut kering. Hal ini diduga saat penambahan PEG pada proses ekstraksi, kandungan lemak ikut terlarut. PEG merupakan senyawa organik eter, dimana lemak memilki sifat tidak larut dalam air, tetapi larut dalam pelarut organik salah satunya adalah eter (Ngili, 2009). Sampel rumput laut yang berasal dari pasar di Jakarta bila dibandingkan dengan hasil tepung agar - agar hasil ekstraknya menunjukkan perbedaan yang signifikan, hal ini diduga disebabkan oleh jenis bahan baku rumput laut kering dan adanya pengotor yang berupa lemak atau minyak yang masih melekat pada bahan baku, sehingga kandungan lemak kasar rumput laut kering di Jakarta lebih besar dibandingkan sampel Bekasi dan Bogor.

\section{Kadar Protein}

Protein merupakan suatu zat makanan yang penting bagi tubuh karena berfungsi sebagai sumber energi, zat pembangun dan zat pengatur (Winarno, 1991). Komponen protein dalam agar agar terdapat dalam jumlah yang kecil dan merupakan komponen pelengkap pada agar-agar. Kadar protein dalam rumput laut kering menurut FAO (1972) adalah sebesar 1,3\% (Fitri, 1992), sedangkan kadar protein pada agar - agar menurut Susanto et. al. (1978) adalah 0,2\%. Hasil analisis kadar protein pada masing masing sampel rumput laut kering dan produk tepung agar - agar hasil ekstrak Bekasi, Jakarta dan Bogor dapat dilihat pada Gambar 9.

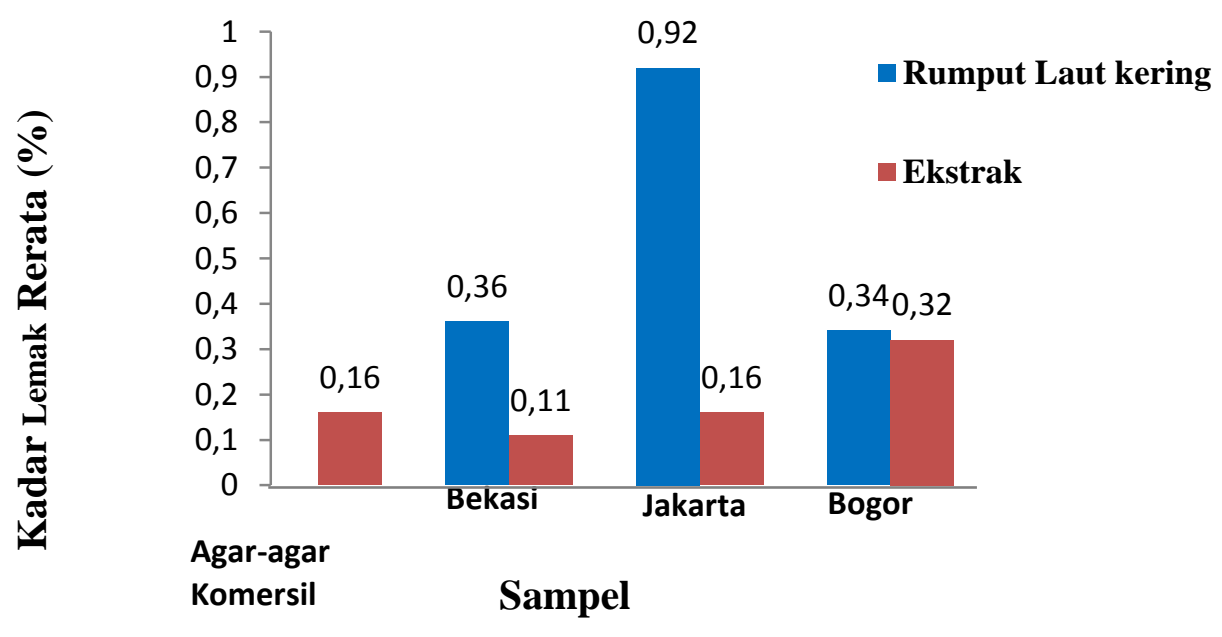

Gambar 8. Kadar Lemak Kasar Rerata pada Rumput Laut Kering dan Hasil Ekstraknya 
Gambar 9 menunjukkan nilai rataan kadar protein pada masing - masing sampel rumput laut kering Bekasi, Jakarta, dan Bogor berturut - turut adalah 2,78\%; $8,78 \%$ dan $1,08 \%$. Sedangkan nilai rataan kadar protein pada masing - masing sampel tepung agar - agar hasil ekstraksi adalah $0,14 \% ; 0,2 \%$; dan $0,22 \%$. Kadar protein sampel tepung agar-agar hasil ekstrak masih memenuhi kadar protein yang disyaratkan Susanto, et.al yaitu sebesar $0,2 \%$ dan bila dibandingkan dengan tepung agar - agar komersil yaitu sebesar $0,12 \%$, menunjukkan hasil yang tidak jauh berbeda.

Kandungan protein pada sampel rumput laut menunjukkan nilai rataan yang tidak memenuhi standar yang disyaratkan oleh FAO (1972) yaitu sebesar 1,3\%. Hal ini diduga pada saat penentuan kandungan protein, senyawa organik yang terdapat dalam sampel rumput laut kering yang merupakan senyawa poli akan hancur menjadi komponen mono yang lebih sederhana. Penambahan $\mathrm{H}_{2} \mathrm{SO}_{4}$ dan $\mathrm{NaOH}$ pada analisis kandungan protein diduga menyebabkan adanya serat kasar yang ikut terhidrolisis, sehingga mengakibatkan kandungan protein yang di analisis menjadi lebih besar.

Berdasarkan data yang diperoleh menunjukkan penurunan yang signifikan sebelum dan sesudah diekstraksi, hal ini diduga pada tahapan praperlakuan alkali dengan menambahkan $\mathrm{NaOH}$, nitrogen yang terdapat dalam sampel terurai dari ikatan organiknya dan dengan pemanasan pada suhu $85^{\circ} \mathrm{C}$ senyawa poli sebagian hancur menjadi senyawa yang sederhana. Hal ini menyebabkan kandungan nitrogen pada sampel tepung agar - agar setelah diekstrak berkurang, sebelum dilakukannya uji kandungan protein.

\section{Kadar Karbohidrat}

Karbohidrat mempunyai peranan yang penting dalam menentukan karakteristik bahan makanan, misalnya rasa, warna, dan tekstur (Winarno, 1991). Pada umumnya karbohidrat ditemukan di alam terdapat sebagai polisakarida dengan berat molekul tinggi. Galaktosa merupakan monomer dari polisakarida yang terbesar yang terdapat di dalam agar-agar. Karbohidrat yang terkandung di dalam agar - agar merupakan campuran polisakarida yang terdiri dari dua fraksi yaitu agarosa dan agaropektin (Rachmat \& Abdullah, 2002).

Kandungan karbohidrat pada rumput laut kering menurut FAO (1972) dalam Fitri (1992) adalah sebesar 83,5\%, sedangkan kandungan karbohidrat dalam agar - agar yang disyaratkan SNI adalah lebih dari 30\% (Angka \& Suhartono, 2000). Hasil penelitian terhadap kandungan karbohidrat yang terdapat pada rumput laut kering dan produk tepung agar-agar hasil ekstrak Bekasi, Jakarta dan Bogor dapat dilihat pada Gambar 10.

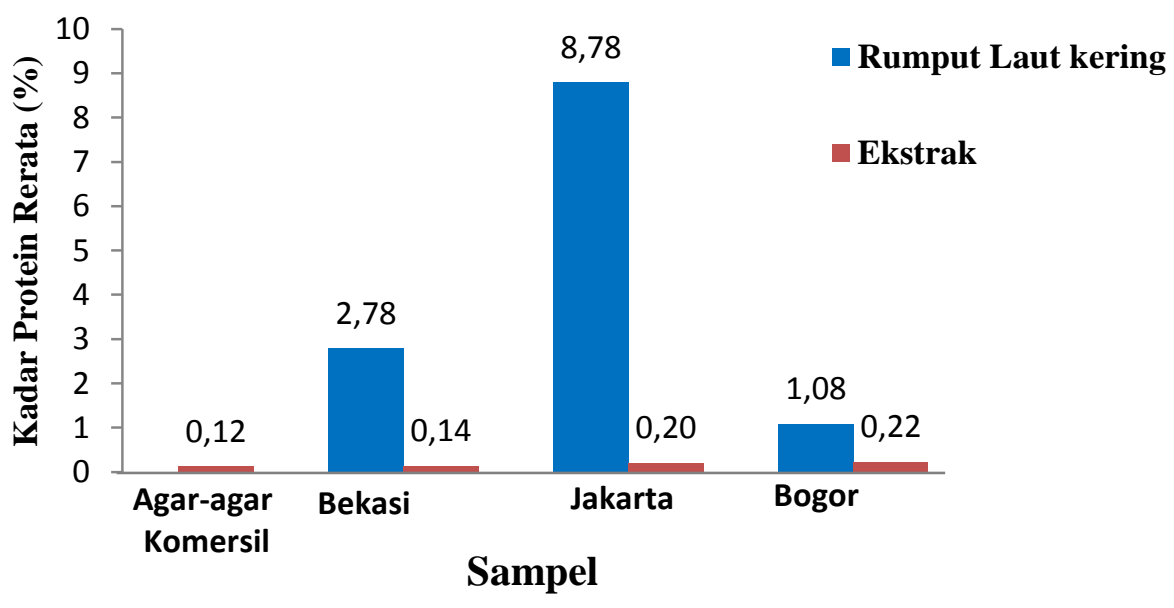

Gambar 9. Kadar Protein Rerata pada Rumput Laut Kering dan Hasil Ekstraknya 


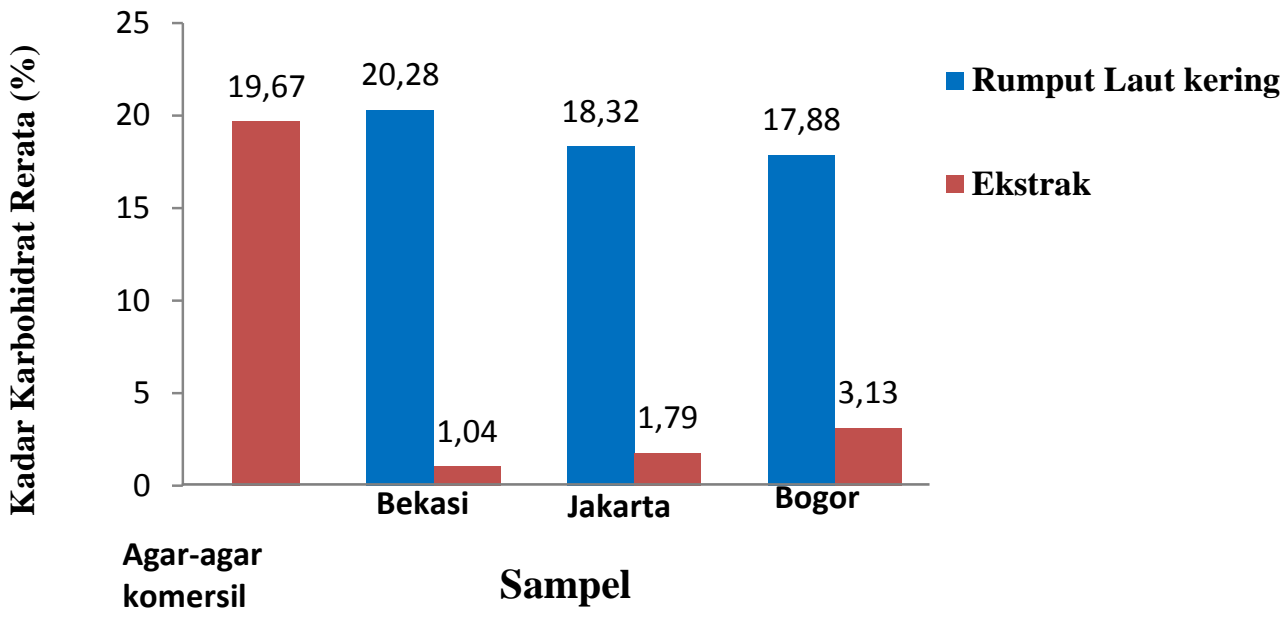

Gambar 10. Kadar Karbohidrat Rerata pada Rumput Laut Kering dan Hasil Ekstraknya

Gambar 10 menunjukkan bahwa nilai rataan kandungan karbohidrat pada masing-masing sampel rumput laut kering Bekasi, Bogor dan Jakarta berturut-turut adalah sebesar 20,28\%; $18,32 \%$ dan $17,88 \%$. Sedangkan kadar karbohidrat setelah diekstraksi pada sampel tersebut masing-masing adalah sebesar $1,04 \%$; $1,79 \%$ dan $3,13 \%$. Kadar karbohidrat masing-masing sampel tepung agar - agar hasil ekstraksi bila dibandingkan dengan sampel tepung agar - agar komersil yaitu sebesar 19,67\%, menunjukkan hasil yang jauh berbeda.

Diketahui bahwa kadar karbohidrat yang diperoleh, belum memenuhi standar yang disyaratkan oleh FAO dan SNI untuk rumput laut kering maupun agar - agar . Kandungan karbohidrat pada sampel rumput laut kering yang rendah, diduga disebabkan oleh jenis rumput laut yang digunakan tidak homogen karena diperoleh dari pasar tradisional serta umur panen pada bahan baku rumput. Menurut Chapman dan Chapman, diacu dalam Fitri (1992), semakin tinggi kandungan karbohidrat agar-agar maka semakin tinggi pula kandungan agarosanya.

Berdasarkan nilai rataan kandungan karbohidrat pada sampel rumput laut kering bila dibandingkan dengan sampel tepung agar - agar hasil ekstrak menunjukkan hasil yang jauh berbeda. Hal ini karena kandungan karbohidrat dalam sampel rumput laut masih merupakan campuran polisakarida yaitu agarosa dan agaropektin. Sedangkan pada sampel agar - agar hasil ekstraksi diduga berasal dari agarosa dan sedikit agaropektin yang masih tersisa di dalam ekstrak agar - agar. Penambahan PEG saat proses ekstraksi belum sepenuhnya memisahkan agarosa dan agaropektin dari bahan baku rumput laut.

\section{Kadar Serat Kasar}

Serat makanan adalah bagian dari bahan makanan yang tahan terhadap proses hidrolisis enzim - enzim pencernaan dalam lambung dan usus halus (Fitri, 1992). Serat kasar (crude fiber) yang biasa digunakan dalam analisis proksimat bahan makanan, merupakan bagian serat makanan yang tidak dapat dihidrolisis oleh $\mathrm{H}_{2} \mathrm{SO}_{4}$ dan $\mathrm{NaOH}$ pada penetuan serat kasar. Pada jumlah sedang serat kasar diperlukan untuk mempermudah kerja sistem percernaan, absropsi berbagai nutrisi, dan memberikan rasa. Hasil penelitian Departemen Kesehatan Jepang menunjukkan bahwa agar - agar merupakan makanan berserat tinggi, sehingga dianjurkan dikonsumsi untuk mencegah penyakit kanker usus, wasir dan obesitas (Anggadireja, et.al, 
2006). Kandungan serat pada rumput laut kering yang disyaratkan oleh FAO (1972) adalah sebesar 2,7\% (Fitri,1992), sedangkan kadar serat untuk agar - agar menurut Susanto, et.al, 1978 adalah sebesar $0,1 \%$.

Hasil penelitian kadar serat kasar pada masing - masing sampel rumput laut kering dan tepung agar - agar hasil ekstrak Bekasi, Jakarta dan Bogor dapat dilihat pada Gambar 11.

Gambar 11 menunjukkan bahwa nilai rataan kadar serat kasar pada sampel rumput laut kering Bekasi, Jakarta, dan Bogor berturut - turut adalah sebesar $14,39 \% ; 12,94 \%$ dan $27,27 \%$. Sedangkan kadar serat kasar pada sampel tepung agaragar hasil ekstraksi Bekasi, Jakarta dan Bogor masing - masing yaitu sebesar $0,79 \% ; 0,84 \%$ dan $0,87 \%$. Kadar serat kasar sampel tepung agar - agar hasil ekstraksi bila dibandingkan dengan sampel tepung agar - agar komersil sebesar $6,32 \%$, menunjukkan hasil yang jauh berbeda.

Diketahui bahwa kandungan serat kasar pada sampel rumput laut kering dan sampel tepung agar - agar hasil ekstrak menunjukkan nilai rataan yang lebih besar bila dibandingkan dengan standar yang disyaratkan menurut FAO dan Susanto, et.al. Hal ini diduga saat terjadi proses hidrolisis dalam asam kuat encer dan basa kuat encer, ada kandungan protein yang ikut terhidrolisis, sehingga kadar serat yang terukur menjadi lebih besar.
Berdasarkan hasil penelitian yang diperoleh dapat diketahui bahwa kandungan serat kasar pada sampel sebelum dan sesudah diekstraksi menunjukkan penurunan yang signifikan. Hal ini disebabkan terjadinya hidrolisis selulosa menjadi monomer - monomer yang lebih sederhana oleh $\mathrm{NaOH}$ pada praperlakuan saat ekstraksi, sehingga serat kasar pada tepung agar - agar berkurang sebelum dilakukannya uji kadar serat kasar.

\section{Kadar Sulfat}

Kandungan sulfat dalam agarosa menunjukkan adanya agaropektin yang masih tersisa dalam agarosa setelah proses pemisahan. Menurut Suryaningrum, et.al (1994) kadar sulfat untuk agar - agar dari Gracilaria sp. tambak sebesar 3.25 4.75\%. Kadar sulfat agarosa berkisar antara $0.03-0.04 \%$ (Chapman \& Chapman, 1980). Agarosa yang umum di pasaran memiliki kandungan sulfat antara $0.1-0.35 \%$, sedangkan agarosa dengan kadar sulfat $<0.05 \%$ tidak tersedia secara luas karena harganya sangat mahal (Sigma-Aldrich, 2002-2003). Metode ekstraksi rumput laut menjadi agar - agar dapat mempengaruhi kandungan sulfat. Proses praperlakuan basa pada tahapan ekstraksi agar - agar akan menghasilkan konsentrasi sulfat yang lebih rendah bila dibandingkan dengan praperlakuan asam (Indriawati, 2007; Phillips \& William, 2000).

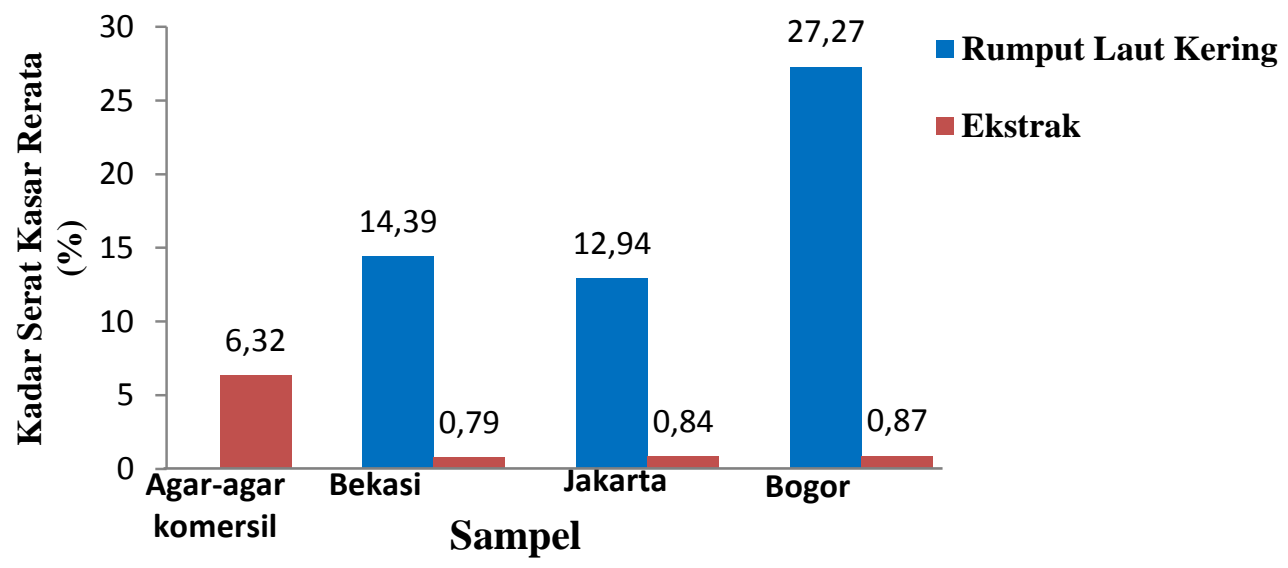

Gambar 11. Kadar Serat Kasar Rerata pada Rumput Laut Kering dan Hasil Ekstraknya 
Konsentrasi sulfat dalam agar agar dapat dipengaruhi oleh kandungan agarosa dan agaropektin. Perbandingan kedua komponen tersebut tergantung pada jenis rumput laut penghasil agar umumnya kandungan agarosa sekitar 55-66\% (Rasyid, 2004b). Menurut Chapman dan Chapman (1980), kandungan sulfat pada agarosa sebesar 0,02-0,04\% sedangkan pada agaopektin sebesar 3,7-9,7\%. Hasil penelitian kadar sulfat pada sampel tepung agar - agar hasil ekstraksi Bekasi, Jakarta dan Bogor dapat dilihat pada Gambar 12.

Gambar 12 menunjukkan bahwa kadar sulfat rataan pada masing-masing sampel tepung agar-agar hasil ekstrak Bekasi, Jakarta dan Bogor berturut - turut adalah sebesar $6,88 \% ; 1,55 \%$ dan $1,07 \%$. Sedangkan kadar sulfat pada sampel tepung agar - agar komersil sebesar $0,85 \%$. Kandungan sulfat yang diperoleh pada sampel, merupakan sulfat yang berasal dari agaropektin yaitu antara $3,7-$ $9,7 \%$.

Kadar sulfat sampel tepung agar agar hasil ekstraksi bila dibandingkan dengan tepung agar - agar komersil lebih besar, hal ini diduga PEG yang ditambahkan pada saat proses ekstraksi tidak memisahkan agarosa dan agaropektin secara sempurna, sehingga sejumlah agaropektin masih terdapat pada sampel tepung agar - agar hasil ekstraksi. Menurut Hugs (1997), kandungan sulfat yang terdapat di dalam agarosa berasal dari sejumlah kecil agaropektin setelah proses pemisahan. Terdapat hubungan antara kadar sulfat yang dihasilkan dengan kekuatan gel dari agar - agar. Kadar sulfat yang semakin tinggi akan membentuk kekuatan gel yang semakin rendah begitupun sebaliknya, kadar sulfat yang rendah akan membentuk kekuatan gel yang tinggi.

\section{Kekuatan Gel}

Kekuatan gel agar - agar sangat tergantung pada perbandingan kandungan agarosa terhadap agaropektin (Winarno, 1996). Gel yang terbentuk akan semakin kuat dengan bertambahnya kadar agarosa (Rasyid, 2004a). Proses pembentukan gel terjadi karena adanya ikatan antar rantai polimer sehingga membentuk struktur tiga dimensi yang mengandung pelarut pada celah - celahnya. Kekuatan gel pada agar agar dapat memberikan tekstur rasa pada makanan.

Proses pengukuran kekuatan gel dilakukan dengan cara menekan permukaan gel dengan beban berbentuk silinder hingga padatan gel retak dan dibaca oleh rekorder yang berupa puncak spektrum. Hasil pengamatan kekuatan gel terhadap sampel agar - agar hasil ekstraksi Jakarta dan Bogor dapat dilihat pada Gambar 13.

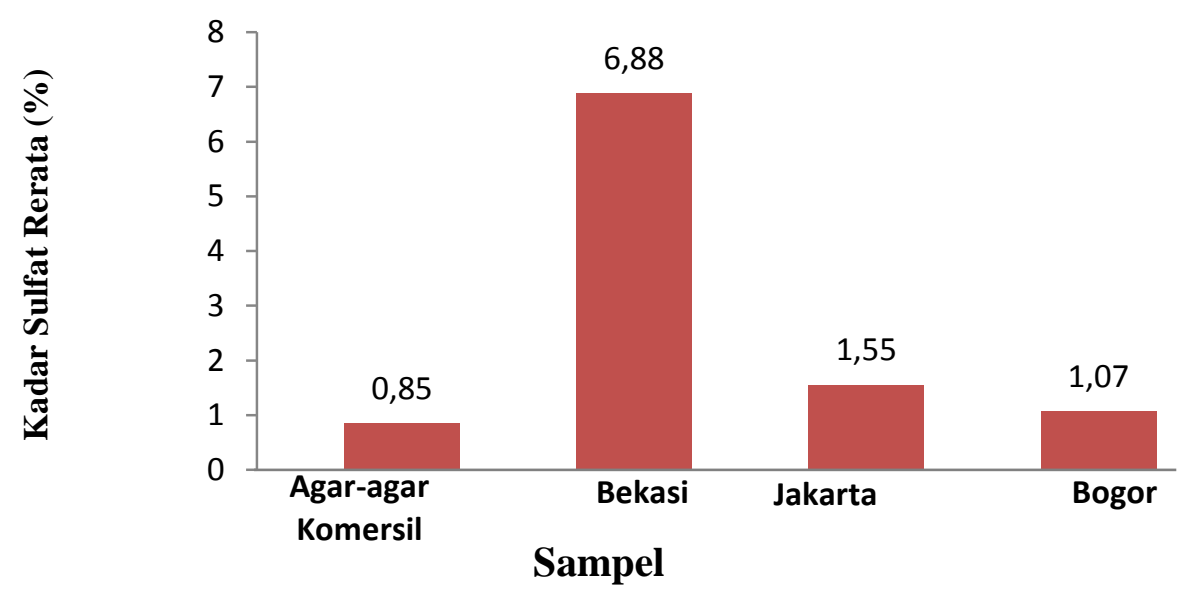

Gambar 12. Kadar Sulfat Rerata pada Sampel Tepung Agar - agar Hasil Ekstraksi. 


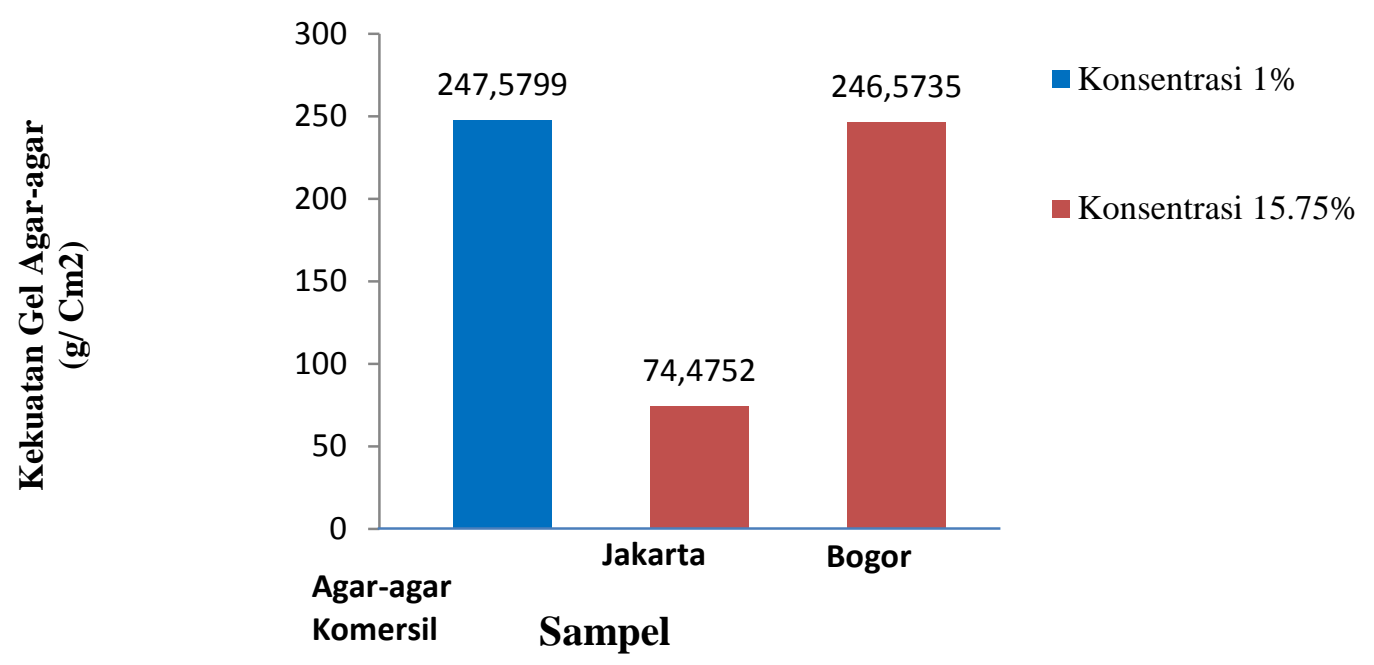

Gambar 13. Kekuatan Gel Rerata pada Sampel Agar-agar Komersial dan Hasil Ekstraksi

Gambar 13 menunjukkan bahwa kekuatan gel rataan pada masing-masing sampel tepung agar - agar hasil ekstrak Jakarta adalah sebesar $74,4752 \mathrm{~g} / \mathrm{cm}^{2}$ pada konsentarsi $15,75 \%$, sedangkan kekuatan gel sampel Bogor sebesar 246,5735 g/ $\mathrm{cm}^{2}$ pada konsentrasi $15,75 \%$. Sedangkan kekuatan gel pada sampel tepung agar agar komersil sebesar $247,5799 \mathrm{~g} / \mathrm{cm}^{2}$ pada konsentrasi $1 \%$. Konsentrasi agar agar pada sampel hasil ekstraksi saat pengukuran kekuatan gel tidak sama dengan sampel komersial, hal ini disebabkan karena pada konsentrasi $1 \%$, gel sampel agar - agar hasil ekstrak Bogor dan Jakarta tidak terbentuk. Gel baru terbentuk saat konsentrasi agar - agar diperbesar menjadi $15,75 \%$ sehingga dapat dilakukan pengukuran kekuatan gel.

Kekuatan gel pada sampel agar agar Bekasi tidak dapat diukur walaupun konsentrasi telah ditingkatkan menjadi $30 \%$, hal ini diduga karena sedikitnya kandungan agarosa yang terdapat dalam ekstrak agar - agar. Besarnya kandungan galaktosa dan kandungan sulfat mempengaruhi kekuatan gel agar - agar. Hal ini dapat dilihat pada Gambar 10 dimana kandungan karbohidrat pada sampel tepung agar - agar Bekasi lebih kecil dibandingkan kedua sampel lainnya yaitu Jakarta dan Bogor, sedangkan kandungan sulfat berbanding terbalik dengan kandungan karbohidratnya.
Semakin tinggi kandungan sulfat dalam sampel agar - agar maka semakin rendah kekuatan gelnya dan sebaliknya.

\section{KESIMPULAN}

Berdasarkan hasil penelitian yang diperoleh dapat disimpulkan bahwa :

1. Sampel tepung agar - agar hasil ekstraksi memiliki kadar kandungan kimia dan kekuatan gel yang berbeda dengan tepung agar - agar komersil.

2. Kadar air tepung agar-agar komersil sebesar $15,08 \%$ jauh lebih tinggi dibandingkan sampel tepung agar agar ekstrak dari Bekasi, Jakarta dan Bogor yaitu sebesar $1,275 \% ; 3,05 \%$ dan $1,27 \%$. Kadar abu tepung agar agar komersil sebesar $0,16 \%$ sedangkan pada sampel tepung agar agar hasil ekstrak dari Bekasi, Jakarta dan Bogor berturut - turut adalah $0,29 \%$; $0,55 \%$; dan $0,3 \%$. Kadar lemak kasar pada tepung agar - agar komersil sebesar $0,16 \%$ sedangkan pada sampel tepung agar - agar, hasil ekstraksi Bekasi, Jakarta dan Bogor masing - masing sebesar $0,11 \%$; $0,16 \%$ dan $0,32 \%$. Kadar protein tepung agar - agar komersil sebesar $0,12 \%$ sedangkan pada sampel tepung agar-agar hasil ekstrak Bekasi, Jakarta dan Bogor masing - masing 
sebesar 0,14\%; 0,2\%; dan 0,22\%. Kandungan karbohidrat tepung agar agar komersil sebesar 19,67\%, sedangkan tepung agar - agar, hasil ekstrak Bekasi, Jakarta dan Bogor berturut-turut adalah $1,04 \% ; 1,79 \%$ dan $3,13 \%$. Kandungan serat kasar yang terdapat pada tepung agar - agar komersil sebesar $6,32 \%$ sedangkan pada tepung agar - agar hasil ekstrak Bekasi, Jakarta, dan Bogor berturut turut adalah $0,79 \% ; 0,84 \%$ dan $0,87 \%$. Kadar sulfat pada tepung agar-agar komersil sebesar 0,85\% sedangkan pada tepung agar - agar hasil ekstrak Bekasi, Jakarta dan Bogor berturut - turut adalah 6,88\%; $1,5 \%$ dan $1,07 \%$. Kekuatan gel agar agar komersil $1 \%$ adalah sebesar 247,5799 $\mathrm{g} / \mathrm{cm}^{2}$ sedangkan pada agaragar hasil ekstrak Jakarta dan Bogor dengan konsentrasi 15,75\% masing masing adalah sebesar $74,4752 \mathrm{~g} / \mathrm{cm}^{2}$ dan 246,5735 g/cm².

3. Sampel dari pasar Bogor memiliki kandungan kimia dan kekuatan gel lebih baik dibandingkan dengan sampel dari pasar Bekasi dan Jakarta.

4. Sampel tepung agar - agar hasil ekstraksi dapat digunakan sebagai bahan makanan.

\section{DAFTAR PUSTAKA}

Anggadireja, J. T., A. Zatnika, H. Purwoto \& S. Istin, 2006. Rumput Laut. Penebar Swadaya. Jakarta

Angka, S. L \& M. T., Suhartono, 2000. Biologi Hasil Laut. Pusat Kajian Sumber Pesisir dan Lautan, IPB. Bogor.

[AOAC] Association of Official Analytical Chemistry, 2000. Official Method of Analysis of the Association of Official Analytical Chemistry. Ed ke-17. Sydney William, editor. Arlington, Virginia : AOAC.

Armeidy, 1992. Pengaruh Konsentrasi Asam dan Lama Perendaman
Optimal Terhadap Rendemen dan Mutu Agar Gracilaria verrucosa. Skripsi. Fakultas Teknologi Pertanian. IPB. Bogor.

Asmarita, 2000. Pengaruh Ukuran Bahan Baku Rumput laut dan Jenis Kain Saring Terhadap Rendemen dan Mutu Tepung Agar - agar. Skripsi. Fakultas Perikanan dan Ilmu Kelautan. IPB. Bogor.

Brooker, D. B., F. W. Baker-Arkema \& C.W. Hall, 1974. Drying Cereal Grains. The AVI Publishing Co.Inc., Westport. Connecticut.

Chapman, V. J \& D. J. Chapman, 1980. Seaweeds and Their Uses. Ed ke-3. Routledge Chapman \& Hall. London

Darmawan, M., Syamdidi \& E. Hastarini, 2006. Pengolahan Bakto Agar dari Rumput Laut Merah (Rhodymenia ciliata) dengan Pra Perlakuan Alkali. Jurnal Pascapanen dan Bioteknologi dan Perikanan. Vol. 1. Nomor 1: 9-18.

Distantina, S., O. Rusman dan S. Hartati, 2006. Pengaruh Konsentrasi Asam Asetat pada Perendaman Terhadap Kecepatan Ekstraksi Agar - agar . Vol. 5. No.1. Hal. 34-39. Universitas Sebelas Maret. Surakarta.

Fellow, P. J., 1992. Food Processing Technology Principles and Practice. Ellis Hourwood Limited. England.

Fitri, E., 1992. Isolasi Agarosa dengan Metode Polyethylene Glycol (PEG Method) dan Agar-agar Gracilaria sp. Skripsi. Fakultas Teknologi Pertanian. IPB. Bogor.

Glicksman, M., 1983. Food Hydrocolloid. Volume ke-2. CRC. Boca Raton, Florida. 
Hall, D. W., 1970. Drying and Storage of Agriculture Crops. Westport, Connecticut : AVI Pr.

Indriani, H \& E. Sumiarsih, 2003. Budidaya Pengolahan dan Pemasaran Rumput Laut. Penebar Swadaya. Jakarta.

Indriawati, K., 2007. Analisis kekuatan gel (gel strength) agar - agar komersial berdasarkan konsentrasi sulfat dan konsentrasi 3,6-anhidroL-galaktosa. Skripsi. Fakultas Matematika dan Ilmu Pengetahuan Alam. Institut Pertanian Bogor. Bogor.

Irawati, A., 1993. Proses Pembuatan Tepung Agar - agar (Gracilaria sp) di PT. Bintang Cibinong Bogor, Jawa Barat. Laporan Praktek Lapangan. Fakultas Perikanan. IPB. Bogor.

Irawati, A., 1994. Pengaruh Jumlah Air dan Waktu Ekstraksi terhadap Rendemen dan Mutu Tepung Agar - agar dari Rumput Laut Gracilaria sp. Skripsi. Fakultas Perikanan. IPB. Bogor.

Istini, S., A. Zatnika \& Suhaimi, 1986. Manfaat dan Pengolahan Rumput Laut. Majalah BPPT : $1-12$. Jakarta.

Johnson, A. H \& M. S. Peterson, 1974. Ecyclopedia of Food Technology. Di dalam Pengaruh Penambahan Iota Karaginan pada Proses Ekstraksi Agarosa dari Rumput Laut Gracilaria chilensis dengan Metode Cetyl Piridinium Chloride. Skripsi. Norman Satriyana. Fakultas Perikanan dan Ilmu Kelautan. IPB. Bogor.

Matsuhashi, T., 1977. Acid Pretreatment of Agarophytes Provides Improvement in Agar Extraction. Journal of Food Science. Vol. 42:5. Hal 1396-1400.
Mc. Hugs, D. J., 1987. Production and Utilization of Product From Commercial Seaweeds. Di dalam Isolasi Agarosa dengan Metode Polyethylene Glycol (PEGMethod) dan Agar - agar Gracilaria sp. Skripsi. Enny Fitri. Fakultas Teknologi Pertanian. IPB. Bogor.

Nasran, S., F. Ariyani, Murdinah \& I. Mulyanah., 1991. Pengaruh Penggunaan Kapur, Air Perebus dan Soda Abu Terhadap Mutu Agar - agar Kertas. Prosiding Temu Karya Ilmiah Teknologi Pasca Panen Rumput Laut II 1112 maret 1991. Pusat Penelitian dan Pengembangan Perikanan. Departemen Pertanian . Jakarta.

Perry, R. H \& D. Green., 1984. Perry's Chemical Engineers Handbook. Ed. Ke-6 : 5-15. Mc Graw-Hill Book. Singapore.

[PPPP] Pusat Penelitian dan Pengembangan Perikanan, 1991. Teknologi Pasca Panen Rumput Laut. Departemen Kelautan. Jakarta.

Priono, B. \& B. Utomo., 1991. Pengaruh Penambahan $\mathrm{NaOH}$ dan $\mathrm{KCl}$ terhadap Sifat Fisika Kimia Agar agar Kertas. Prosiding Тети Karya Ilmiah Teknologi Pasca Panen Rumput Laut II 11 - 12 Maret 1991. SBPPL No 04/TKI.TPPRL/91. Sub Balitkanlut. Jakarta.

Rachmad, R. \& R. Abdullah, 2002. Ekstraksi Agarose dari Agarofit Gracillaria Verrucosa. Hal. 138145. Prosiding Seminar Nasional Rumput Laut dan Mini Symposium Mikroalgae 23-25 Oktober 2002. Ikatan Fikologi Indonesia. Jakarta.

Rasyid, A., 2004a. Beberapa Catatan Tentang Agar. Vol 2. Hal. 1 - 7. 
Puslitbang Oseanologi LIPI. Jakarta

Rasyid, A., 2004b. Berbagai Manfaat Algae. Vol 3. Hal. 9-15. Puslitbang Oseanologi LIPI. Jakarta

Rasyid, A., R. Rachmat \& T. Murniasih, 1999. Karakteristik Polisakarida Agar dari Gracilaria sp. dan Gelidium sp. Hal. 57-62. Puslitbang Oseanologi-LIPI. Jakarta.

Satriyana \& Norman, 2002. Pengaruh Penambahan Iota Karaginan pada Proses Ekstraksi Agarosa dari Rumput Laut Gracilaria chilensis dengan Metode Cetyl Piridinium Chloride. Skripsi. Fakultas Perikanan dan Ilmu Kelautan. IPB. Bogor.

Shelby, H. H. \& W. H. Wayne, 1973. Agar. R.L., Whisler \& J.M.B., Miller (ed). Gum Technology. Ed ke -2 . Academic Pr. New York.

Sigma-Aldrich., $2002-2003$. Biochemicals and Reagents for Life Science Research: 2872.

Soegianto, S., W. S. Atmadja \& H. Mubarak, 1978. Rumput Laut (Algae): Manfaat, Potensi, dan Usaha Budidaya. Lembaga Oseanologi Nasional-LIPI. Jakarta.

Soegiarto, A. \& Sulistyo, 1985. Produksi dan Budidaya Rumput Laut di Indonesia. Lembaga Oseanologi Nasional-LIPI. Jakarta.

Subaryono, B. S. B. Utomo, T., Wikanta, N. Satriyana, 2003. Pengaruh Penambahan Iota Karaginan pada Ekstraksi Agarosa dari Agar - agar menggunakan Cetyl piridium Klorida. Jurnal Penelitian Perikanan Indonesia. Vol. 9. Nomor $5: 1-9$.
Suryaningrum, T. D, J. T., Murtini, S. Wibowo dan M. Suherman., 1994. Kajian Sifat Fisik dan Oragoleptik Tepung Agar - agar dari Rumput Laut Gracilaria Tambak. Jurnal Pasca Panen Perikanan (83) : 1 12.

Susanto, P. Mulyono, Lappas \& S. Endang, 1978. Penelitian Agar agar pada Bermacam - macam Jenis Sango-sango (Rumput Laut) di Sepanjang Pantai Makasar. Balai Penelitian Kimia. Ujung Pandang.

Stanley, N. F., 1996. Standard Practice Instructions C 19. Marine Colloid, Inc. Rocland, Marine: 4.

Tanikawa, E., 1985. Marine Products in Japan. Koseisha Koseikaku Co. Ltd. Tokyo.

Utomo, B. S. B. \& N. Satriyana, 2006. Sifat Fisiko - Kimia Agar - agar dari Rumput Laut Gracilaria chilensis yang Diekstrak Dengan Jumlah Air yang Berbeda. Jurnal Ilmu-ilmu Perairan dan Perikanan Indonesia. Jilid 13. Nomor $1: 45-$ 50 .

Winarno, F. G., 1991. Kimia Pangan dan Gizi. Gramedia Pustaka Utama. Jakarta.

Winarno, F. G., 1996. Teknologi Pengolahan Rumput Laut. Pustaka Sinar Harapan. Jakarta. 